\title{
AMHTS における胆石の指導
}

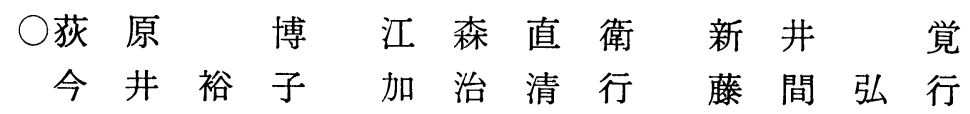

現在，超音波猃断装置の飛躍的進歩には目をみはるも のがある。今回は藤間病院 AMHTS に於ける腹部超音 波診断の成績を検討し，有所見の中で最も数の多い胆石 の指導について現況を述べ，参考に供したい。

昭和 55 年 7 月より 58 年 12 月に至る 3 年半で, 検査総数 は24,297名。主たる検查目的は胆のう疾患の有無で, 使 用機種は SAL-20A，リニア電子走査型。検査時間は約 5 分間である。有所見者は 1,545 名 $(6.36 \%)$, 内胆石 は730名 $(3.00 \%)$ と圧倒的に多く, 以下胆石疑 147 名 $(0.61 \%)$, 肝のう胞 216 名 $(0.89 \%)$, 腎のう胞 188 名 $(0.77 \%)$, 胆の5隆起性病変 117 名 $(0.48 \%)$, 肝内結石 51 名 $(0.21 \%)$ ，腎結石 41 名 $(0.17 \%)$ などであった。

胆のう内結石の典型的な超音波画像は, 胆のう内腔に 認められる Strong Echo (SE) と，それに続くAcoustic Shadow（AS）である。

胆石及び胆石疑の者は腹単 $\mathrm{x}-\mathrm{p}$ 撮影後, 超音波再検 を行う。腹単 $\mathrm{x}-\mathrm{p}$ で胆石陰影陰珄, 大きさ $1 \mathrm{~cm}$ 以下, 胆のう収縮率 $30 \%$ 以上で, 乙かも無症状の症例に経口的 胆石溶解剤 (CDCA) を投与している。即ち, 無症状で, 外殼石灰化のないコレステロール系石で, 胆のう機能良 好な石のあまり大きくない症例が適応と考えている。

九大の中山らは, 剖検例の検索から無症状胆石の頻度 を60〜80\%と報告しているが，藤間病院 AMHTS では 90\%が無症状である。

Sweden の Robertson らは無症状胆石781例を11年間 に渡り追跡し, 内 $51 \%$ が有症状となり, 更に $18 \%$ は黄 㾝・急性胆のう炎・脺炎などの重篤な合併症を呈したと 報告している。無症状でも決っして油断はできない。

また, 諸家の報告に見るように, 胆石症の胆のう癌合 併率は3〜10数\%と高く, 胆石のない人の実に 10 倍以上 の発生率である。発癌のリスクは加龄と共に高まり, 特 に60歳以上の女性では高率である。一方, 胆のう癌の胆 石合併率を見ると，50〜90\%と非常に高率で，胆石が発
癌の重要な要素の一つであると言えよう。

以上のようなリスクを考光合わせてみると，AMHTS でせっかく胆石を発見しながら，「しばらく様子を見ま しょう……」といった消極的経過観察ではあまり意味 がないと言わざるを得ない。我々は有症状は原則として 手術。無症状胆石は適応内であれば CDCA 投与。適応 外はやはり原則として手術と考学，指導している。胆石 を発見したらなるべく早い時期に積極的な治療を始め る方が得策と考えているからである。

コレステロール・胆汁酸・レシチンの三者がある一定 の比率で胆汁中に存在する場合, 胆石の生成はないが, 胆汁酸の腸肝循環量の減少や肝でのコレステロール合成 の艺進などにより，三者のバランスがコレステロール過 剩の方に崩れると, 胆石生成につながる。

CDCA 経口投与法は, 胆石では半減しているケノデ オキシュール酸を経口的に補い, 胆汁酸の腸肝循環量を 増大させると共に, CDCA 自身強力なコレステロール 可溶化力を有しており, 更に肝内でのコレステロール合 成にも抑制的に働き, コレステロール過飽和胆汁を不飽 和化し，溶解作用を発揮すると言われている。

我々は固型寒天中に胆石を埋め込み, 胆石の最長径計 測誤差の実験モデルを作成した。超音波画像で計測した 胆石最長径と, 実際の最長径との平均誤差は $1 \mathrm{~mm}$ で, 溶解剂投与症例に拈ける $2 \mathrm{~mm}$ 以上の縮少を有効と判 定した。

投与期間 3 ケ月以上 6 ケ月末満 では 37 名中 9 名 $(24$ $\%), 6$ ヶ月以上 10 ケ月未満では 7 名中 2 名 $(29 \%)$, 全 体では44名中11名 (25\%) が有効例と判定した。最長径 において平均 $3.75 \mathrm{~mm}$ の縮少であった。今後更に症例 をかさねて，その効果を観察していくつもりである。

以上, 藤間病院 AMHTS における胆石の指導の現況 を述べると共に, CDCA 経口投与の効果に関する第1報 を報告した。

\footnotetext{
The guidance for gallstone patients in AMHTS

藤間病院総合健診システム
} 